\title{
Effect of Thermal Treatment of Chamomile (Marticaria chamomella) Extract on the Growth Inhibition of Some Pathogenic Fungi
}

\author{
Al-Meshal Areej Suliman (10 \\ Department of Biology, College of Science and Humanities in Alkharj, Prince Sattam bin Abdulaziz University, \\ Alkharj 11942, Saudi Arabia.
}

\begin{abstract}
This Study shows the effect of thermal treatment of chamomile (Marticaria chamomella) extract with different concentrations $(5,10,15,20,25,30) \mathrm{mg} / \mathrm{ml}$, on inhibition of some pathogenic fungi such as Trichophyton rubrum and Aspergillus fumigatus under the different temperature degrees $(25,50,75$, $100)^{\circ} \mathrm{C}$. The aqueous extract of chamomile gave complete inhibition against the fungus Trichophyton rubrum at $(20,25,30) \mathrm{mg} / \mathrm{ml}$ under temperatures of $(25,50,75,100)^{\circ} \mathrm{C}$ While, the aqueous extract of chamomile gave complete inhibition against the fungus Aspergillus fumigatus at concentrations $(25,30)$ $\mathrm{mg} / \mathrm{ml}$ under the temperature degree of $(75,100)^{\circ} \mathrm{C}$.
\end{abstract}

Keywords: Trichophyton rubrum, Aspergillus fumigatus, chamomile

\footnotetext{
*Correspondence: a.almashal@psau.edu.sa.
}

(Received: November 08, 2020; accepted: December 03 2020)

Citation: Suliman AI-MA. Effect of Thermal Treatment of Chamomile (Marticaria chamomella) Extract on the Growth Inhibition of Some Pathogenic Fungi. J Pure Appl Microbiol. 2020;14(4):2683-2689. doi: 10.22207/JPAM.14.4.46

(c) The Author(s) 2020. Open Access. This article is distributed under the terms of the Creative Commons Attribution 4.0 International License which permits unrestricted use, sharing, distribution, and reproduction in any medium, provided you give appropriate credit to the original author(s) and the source, provide a link to the Creative Commons license, and indicate if changes were made. 


\section{INTRODUCTION}

The term "mycoses" is usually used to describe a range of fungal infections, including superficial mycoses (involving the skin) and systemic mycoses (involving the tissues and internal organs) (Edmonds, 1978). Dermatophytes are interconnected fungi that can invade keratinized tissues in the hair, skin, and nails of human beings and animals. The infection caused by these fungi is called dermatophytoses or ringworms. These fungi include three genera: Trichophyton spp., Microsporum spp., and Epidermophyton spp. (Matsumato, 1996). The development of human skin fungal infections is related to the host's immune status, as well as environmental factors, such as temperature and humidity (Evans, 1997).

Dermatophytes are classified into three main groups according to the natural host

1. Anthropophilic- when humans are the natural host; transmitted via contact with an infected individual

2. Zoophilic- when animals are the natural host; transmitted from animals to human beings

3. Geophilic- species that live in the soil and depend on saprotrophic nutrition from the keratinized materials (hair and feather); transmitted from the soil to human beings and animals.

In general, the zoophilic group causes severe inflammation more than that by the anthropophilic group (Hunter et al., 2002).

Molds are filamentous fungi that have fast-growing hyphae. These molds spread rapidly in the air and soil, causing contamination and infection. Aspergillus is one of the molds' genera, which includes tens of species, characterized by its divided hyphae that branch at $45^{\circ} \mathrm{C}$, producing canidae (non-sexual spores). The three essential species that cause diseases in humans are $A$. flavus, $A$. niger, and $A$. fumigatus. A. fumigatus is one of the most essential fungal species found commonly in the environment and whose airborne spores can cause respiratory allergies (Georgopapdajou,2002). Aspergillosis affects immune-compromised patients (Bodey,1988). A. fumigatus can also cause pulmonary prophylillosis, which is similar to tuberculosis, and produces harmful toxins, including gilotoxins and verrucullogen. These toxins are the leading causes of fungal pathogenicity (Pitt and Hocking,
1997- Koneman et al., 1979; Emmons et al., 1970 and Virella, 1997).

Medicinal plants with pharmacologic and therapeutic properties are the future of the pharmaceutical field at the national, regional, and global level. These plants and their secondary products include volatile oils that can effectively cure the disease with high efficacy. Therefore, studies on medicinal plants have gained a considerable amount of interest among researchers in the advanced and developing countries, as the therapeutic benefits of these plants are not associated with any side effects, which would otherwise occur when using chemically manufactured drugs.

The chamomile plant (Maricaria chamomilla) is a member of the compound family, Compositae, also known as chrysanthemum (Chakravarty, 1976). The chamomile is a herbaceous plant, and its height ranges from 20 to $50 \mathrm{~cm}$. The stem is shabby, highly branched, and the flowers are white and yellow in the center; the heads are cubical and tubular in the middle, edges are cylindrical, stand on a hollow conical base, and have a pungent aroma (Qubaisi, 1998).

The chamomile plant is one of the most globally famous medical plants as it contains several active compounds. A few studies have reported the identification of many of these compounds, and their medical efficiency was investigated (Majeed and Mahmoud,1988). The inflorescence of this plant is known to possess great medical value; some compounds, such as volatile oils, are extracted from dry flowers, and these oils contain several acids, which are used for therapeutic purposes. The inflorescences also contain flavones (hydroxyl coumarins), 10\% gelatinous substances, vitamin $\mathrm{C}$ as well as other free elements, including anthemic acid (Newalland phillpson,1996).

The active ingredient of the chamomile plant extract is the volatile oil, which is estimated to constitute $7 \%$ of the total extract content, and is composed of monofunctional esters, aliphatic acids, and alcohols (Bruneton, 1999). The other active ingredients of chamomile are bisabolol oxides, chamazulene, apigenin (E)beta-farnesene, bisablon, and oxides A, B (Arak, 1981; Revenchon and Senatore,1994). The flower heads of chamomile contain volatile blue 
oil, that constitutes the compound azulene, and azulene is also known as chamazulene, matricin, palustrine, herniarin, dihydroxycinamicacid, quercetin, apigenine, and flavonoids (Gardiner, 2000; Moustafa,2004). Azulene also contains the derivative, angelic acid esters, such as methyl, methylallangelate, isomylangelates, isboutylangelate, and butylangelate (MimicaDukic et al., 2008; Newall et al.,1996). The main oil contains monoterpenes, azulene, and chamazulene. The other active components of the flower are carboxylic and phenolic acids (caffeic, ferulic, coumarins, Tanik, and anthemic acids), flavonoids (apigenin and leuteolin), and resin derivatives. Chamomile is considered to relieve stomach discomfort, stomach pain, aperitif, as well as spasms, activate circulation, especially among children, cure eye infections, and relax the nerves. Chamomile oil is used in compressors to remove chest pain in pneumonia (Mann and stab,1986). The flowers are also widely used in Europe as an alternative to morning tea, after being sweetened, to prevent cold flu. It is used in the aromatherapy industry and has external use in the treatment of summer wounds. Inflorescences have yellow plant pigments, namely, apigenin. They are used to manufacture cosmetics, especially hair products, including those used in hair dye, as well as facial skin cosmetics, such as creams and face soaps (Liang et al.,1999).

Given the importance and ease of obtaining chamomile, and as studies on its effect on some pathological fungi are limited, we aimed to test the following:

1. The disincentive effect of chamomile extract on some pathogenic fungi;

2. The effect of thermal treatments on the chamomile plant extract's disincentive effect on some pathogenic fungi.

\section{MATERIALS AND METHODS}

Pathological samples were collected from patients with pathogenic fungal infections. After sterilizing the affected area with $70 \%$ ethyl alcohol, samples were collected from skin scrapings, nails, and sputum.

\section{Isolation of Fungi}

Direct Microscopy and Implantation of Samples

Few skin scrapings or the soft keratinized remains of the nails were collected using either a sterile scalpel or surgical blade or sterile forceps, respectively, and the samples were placed on clean slides. A drop of potassium hydroxide solution was added, and the slide was covered and heated by moving it over a Bunsen burner flame twice or thrice, while avoiding boiling as it leads to potassium hydroxide crystallization. Then, the slide was left for $20 \mathrm{~min}$ and squeezed gently with the loop base. All the slides were prepared under the microscope; the slides were examined first at $\times 10$ and then at $\times 40$ magnification to observe the hyphae and arthrospores (Szepietoeski and Schwart, 2005). Positive samples were then plated on Petri dishes containing Sabouraud dextrose agar (SDA); the dishes were incubated at $25^{\circ} \mathrm{C}$ for 7-14 $d$ and checked every 2-3 $d$ (Eilabib and khalifa,2001).

To isolate the molds, ear swabs were collected from the infected outer ear using a sterile cotton swab. Additionally, the oral cavity was sterilized by gargling with saline in the morning and the sputum samples were then collected. These samples were examined under a microscope to investigate the presence of molds, plated on a sterile medium, and then incubated at $25^{\circ} \mathrm{C}$ for 1 week (Beneke and Rogers1980; Jawetz et al., 1987). The fungi were isolated and purified later.

\section{Identification of the Isolated Fungi}

A part of the fungal growth was scraped using a sterile needle, under a microscope, and placed on a glass slide with a drop of methylene blue. The sample was spread and covered by the slide cover, and then examined under a microscope to observe the fungal yarn and spores. Following observation, the samples were classified according to the approved classification levels (Pitt and Hocking, 1997; Forbes et al., 2002; Koneman et al., 1979).

Extract Preparation: This process includes the following steps

Aqueous Extract Preparation

The aqueous extract was prepared from the used parts of the plant (inflorescence) according to a previously reported method (Rios et al., 1987). For this, $40 \mathrm{~g}$ of the plant powder was blended with $160 \mathrm{~mL}$ of distilled water (1: 4, mass:volume). The plant was ground using a ceramic bowl and mashed using an electric blender (Ultra-Tarax blender Germany), and the mixture was incubated in the refrigerator for 24 
$\mathrm{h}$ for soaking. The mixture was first filtered using several gauze layers and filtered again using the Buchner Bass funnel with filter papers. Finally, the filter was centrifuged to ensure the disposal of all impurities. Thus, the raw aqueous extract for each plant was obtained, and the extract was filled in $25 \mathrm{~mL}$ plastic bottles, frozen in a freezer, and placed in a lyophilizer (Edward High Vacuu V. K Company) under rarefied pressure, at $-50^{\circ} \mathrm{C}$; the samples were freeze-stored in sealed plastic containers.

\section{Water Extract Sterilization}

One gram of the raw dried plant extract was dissolved in $5 \mathrm{~mL}$ of distilled water to sterilize the aqueous extract of chamomile; therefore, an extract with a concentration of $200 \mathrm{mg} /$ $\mathrm{mL}$ was obtained. This $200 \mathrm{mg} / \mathrm{mL}$ extract was sterilized using a $0.22-\mu \mathrm{m}$ diameter Seitz filter. This concentration is considered the source for preparing the diluted solutions used in a previously reported study (Al-Noaman, 1998).

Testing the Disincentive Effect of Chamomile Extract on some Pathogenic Fungi

After preparing and sterilization the aqueous extract of the chamomile plant, it was placed in a water bath at different temperatures, $25,50,75$, and $100^{\circ} \mathrm{C}$, and for the time points, $5,7,10$, and 15 minutes, respectively. Then, the inhibitory effect on the isolated fungi was tested by adding specific volumes of the aqueous extract (exposed to the aforementioned varying factors) to specific sizes of the unsolidified, sterilized SDA in $120-\mathrm{mL}$ glass bottles. The bottles were shaken well, and the extract concentrations $(5,10,15$, 20,25 , and $30 \mathrm{mg} / \mathrm{ml}$, obtained according to the N1V1=N2V2 equation), were then poured into three 9-cm Petri dishes. After medium solidification, a 5-mm diameter disc, from the edge of the A. fumigatus fungal colony ( 1 week old) and that of the T. rubrum colony (10 d-2 weeks old) was cut using a cork borer. The disc was placed at the center of the dish under sterile conditions. The dishes were then incubated in a Memert (Germany) incubator at $25^{\circ} \mathrm{C}$ for 1 week for $A$. fumigatus, and $10 \mathrm{~d}-2$ weeks for $T$. rubrum fungus. The growth of the colonies were observed and the average length of two orthogonal diameters for each fungal colony was measured. This extract treatment was performed in triplicate. As for the control, the extract was not added to the medium (Pitt and Hocking, 1997).

\section{RESULTS AND DISCUSSION}

The morphological features, including the shape, color, texture, and pigment secretions, of the fungal colonies were observed (Fig. (1) and (2)). These results indicated that the aqueous extract of chamomile flowers had different effects on the fungi used in this study. The disincentive effect was clear for T. rubrum in 5, 10, 15, 20, 25, $30 \mathrm{mg} /$ $\mathrm{ml}$ concentrations, under different temperatures and time points. T. rubrum was inhibited entirely at $25,50,75$, and $100^{\circ} \mathrm{C}$. Additionally, at other concentrations, $5,10,15 \mathrm{mg} / \mathrm{ml}$, the average fungal colony diameter was $0,3.5,2$, and $10 \mathrm{~cm}$, respectively, at $25^{\circ} \mathrm{C}$, while the average fungal colony diameters at the same concentrations and at 50,75 , and $100^{\circ} \mathrm{C}$ were $5,0 \mathrm{~cm}$, respectively; thus, a complete disincentive effect was observed. The average fungus colony diameter at other concentrations, $20,25,30 \mathrm{mg} / \mathrm{ml}$ was 5 and $0 \mathrm{~cm}$, respectively; thus, a complete disincentive effect was observed under all the used temperatures, as mentioned in Table (1). This was because the temperature and the active substances have a varying role in inhibiting fungal growth. The high temperatures used in the study as well as the active substances present in the aqueous extract

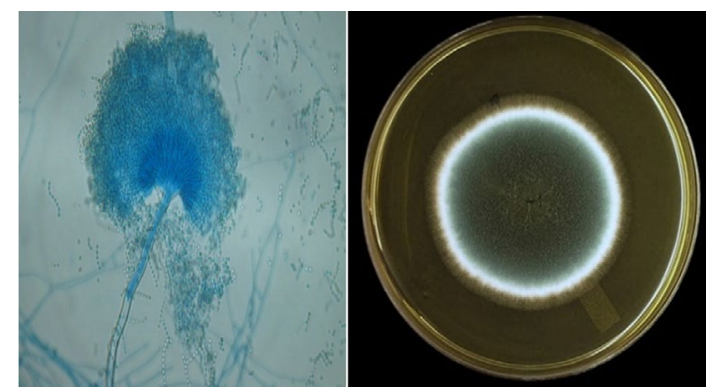

Fig. 2. Shows: Aspergillus fumigatus

Fig. 1. Shows: Trichophyton rubrum 
of chamomile have a significant impact in the inhibition of fungal growth. This difference in inhibition is due to the substances dissolved in water, such as glycosides and chlorides (Harborne, 1973).

This is consistent with Alanzi (2001), who found that the aqueous extract of chamomile inhibited the growth of $T$. mentagraphyte fungus by $50 \%$ at a concentration of $25 \mathrm{mg} / \mathrm{ml}$, while Kharoufa (1999) found that the aqueous extract of chamomile has a high disincentive effect on $T$. vaginalis. Additionally, Mohammed et al (2001) also found that the aqueous extract of chamomile has $100 \%$ disincentive effect on T. Mentgraphytest, A. niger, A.fumigatus, and Candida albicans.

Table 1. The effect of thermal treatments of aqueous chamomile extract on the effectiveness of inhibition growth of Trichophyton rubrum

\begin{tabular}{|c|c|c|}
\hline $\begin{array}{l}\text { Concen. } \\
\text { (mg\ml) }\end{array}$ & Temp. ${ }^{\circ} \mathrm{C}$ & $\begin{array}{l}\text { The Average of Fungus } \\
\text { Colony Diameters (cm) }\end{array}$ \\
\hline \multirow[t]{4}{*}{5} & 25 & $3.0 \mathrm{~d}$ \\
\hline & 50 & $0.5 \mathrm{a}$ \\
\hline & 75 & $0.5 \mathrm{a}$ \\
\hline & 100 & $0.5 \mathrm{a}$ \\
\hline \multirow[t]{4}{*}{10} & 25 & $2.5 \mathrm{c}$ \\
\hline & 50 & $0.5 \mathrm{a}$ \\
\hline & 75 & $0.5 \mathrm{a}$ \\
\hline & 100 & $0.5 \mathrm{a}$ \\
\hline \multirow[t]{4}{*}{15} & 25 & $1.0 \mathrm{~b}$ \\
\hline & 50 & $0.5 \mathrm{a}$ \\
\hline & 75 & $0.5 \mathrm{a}$ \\
\hline & 100 & $0.5 \mathrm{a}$ \\
\hline \multirow[t]{4}{*}{20} & 25 & $0.5 \mathrm{a}$ \\
\hline & 50 & $0.5 \mathrm{a}$ \\
\hline & 75 & $0.5 \mathrm{a}$ \\
\hline & 100 & $0.5 \mathrm{a}$ \\
\hline \multirow[t]{4}{*}{25} & 25 & $0.5 \mathrm{a}$ \\
\hline & 50 & $0.5 \mathrm{a}$ \\
\hline & 75 & $0.5 \mathrm{a}$ \\
\hline & 100 & $0.5 \mathrm{a}$ \\
\hline \multirow[t]{4}{*}{30} & 25 & $0.5 \mathrm{a}$ \\
\hline & 50 & $0.5 \mathrm{a}$ \\
\hline & 75 & $0.5 \mathrm{a}$ \\
\hline & 100 & $0.5 \mathrm{a}$ \\
\hline \multicolumn{2}{|c|}{ Control } & $4.0 \mathrm{e}$ \\
\hline
\end{tabular}

1-Every treatment is the average of three repeats (each repeat is one plate).

2-Values with the same or more letter have no significant difference according to Duncan's new multiple range test at probability level $=0.05$.
Upon studying the aqueous chamomile extract, it was revealed that the extract has a different inhibitory effect against $A$. fumigatus at concentrations, 5, 10, 15, 20, 25, $30 \mathrm{mg} / \mathrm{ml}$, and under the aforementioned temperatures and time points. At concentrations 25 and $30 \mathrm{mg} / \mathrm{ml}$, the fungal growth was totally inhibited under 25, $50,75,100^{\circ} \mathrm{C}$, while the fungal growth was not completely inhibited at $20 \mathrm{mg} / \mathrm{ml}$ under 25 and $50^{\circ} \mathrm{C}$, as the average diameter of the colony was 1.0 and $0.9 \mathrm{~cm}$, respectively. This is inconsistent with the results reported by Al-Anezi (2001), as the aqueous chamomile extract strongly inhibited the growth of $A$. fumigatus (100\% inhibition) at a concentration of $20 \mathrm{mg} / \mathrm{ml}$. Similarly, our results

Table 2. The effect of thermal treatments of aqueous chamomile extract on the effectiveness of inhibition growth of Aspergillus fumigatus

\begin{tabular}{|c|c|c|}
\hline $\begin{array}{l}\text { Concen. } \\
\text { (mg\ml) }\end{array}$ & Temp. ${ }^{\circ} \mathrm{C}$ & $\begin{array}{l}\text { The Average of Fungus } \\
\text { Colony Diameters }(\mathrm{cm})\end{array}$ \\
\hline \multirow[t]{4}{*}{5} & 25 & $3.1 \mathrm{~d}$ \\
\hline & 50 & $3.0 \mathrm{~d}$ \\
\hline & 75 & $0.5 a$ \\
\hline & 100 & $0.5 \mathrm{a}$ \\
\hline \multirow[t]{4}{*}{10} & 25 & $2.7 \mathrm{c}$ \\
\hline & 50 & $2.9 \mathrm{~d}$ \\
\hline & 75 & $0.5 \mathrm{a}$ \\
\hline & 100 & $0.5 a$ \\
\hline \multirow[t]{4}{*}{15} & 25 & $2.0 \mathrm{c}$ \\
\hline & 50 & $1.5 \mathrm{~b}$ \\
\hline & 75 & $0.5 \mathrm{a}$ \\
\hline & 100 & $0.5 \mathrm{a}$ \\
\hline \multirow[t]{4}{*}{20} & 25 & $1.0 \mathrm{~b}$ \\
\hline & 50 & $0.9 \mathrm{~b}$ \\
\hline & 75 & $0.5 \mathrm{a}$ \\
\hline & 100 & $0.5 \mathrm{a}$ \\
\hline \multirow[t]{4}{*}{25} & 25 & $0.5 \mathrm{a}$ \\
\hline & 50 & $0.5 \mathrm{a}$ \\
\hline & 75 & $0.5 \mathrm{a}$ \\
\hline & 100 & $0.5 \mathrm{a}$ \\
\hline \multirow[t]{4}{*}{30} & 25 & $0.5 \mathrm{a}$ \\
\hline & 50 & $0.5 \mathrm{a}$ \\
\hline & 75 & $0.5 \mathrm{a}$ \\
\hline & 100 & $0.5 \mathrm{a}$ \\
\hline Control & & $4.0 \mathrm{e}$ \\
\hline
\end{tabular}

1-Every treatment is the average of three repeats (each repeat is one plate)

2-Values with the same or more letter have no significant difference according to Duncan's new multiple range test at probability level $=0.05$. 
are not in agreement with those of Muhammad et al (2001), which revealed that the aqueous chamomile extract had a $100 \%$ inhibitory effect on A. fumigatus, and at $15 \mathrm{mg} / \mathrm{ml}$ and $50.25^{\circ} \mathrm{C}$, the average diameter of the colony was 2.0 and $1.5 \mathrm{~cm}$, respectively. As for the rest of the temperatures under the same concentration, there was no complete inhibition. At $10 \mathrm{mg} / \mathrm{ml}$ $50.25^{\circ} \mathrm{C}$, no complete inhibition was observed, where the average diameter of inhibition was 2.7 and $2.9 \mathrm{~cm}$, respectively. At 100 and $75^{\circ} \mathrm{C}$, the inhibition was inactivated entirely, as the average diameter of the fungus colony was $0.5 \mathrm{~cm}$ under the same concentration. In contrast, at $5 \mathrm{mg} / \mathrm{mL}$, there was no complete inhibition of the fungus at 25 and $50^{\circ} \mathrm{C}$, as average diameter was 3.1 and $3.0 \mathrm{~cm}$, respectively; however, at 75 and $100^{\circ} \mathrm{C}$, the inhibition was completely inactivated. At 25 and $30 \mathrm{mg} / \mathrm{mL}$, the average colony diameter was 0 and $5 \mathrm{~cm}$, respectively, and complete inhibition was also observed at all temperatures used in the study (Table 2). Significant differences were found between the inhibitory effects of the extract and the control. The reason is that the temperature and active substances have a role in inhibiting the fungus' growth to varying degrees, as the high temperatures are well affected with well-dissolved active substances in the aqueous chamomile extract. This disparity in inhibition is attributed to water-soluble substances, such as glycosides and chlorides (Harborne, 1973) and because chamomile flowers contain plant oil that has an anti-effect against various types of fungi (Ahmed et al., 1994).

\section{ACKNOWLEDGMENTS}

I would like to thank Prince Sattam bin Abdulaziz University for allowing us to use special laboratories in the Department of Biology for performing laboratory experiments.

\section{FUNDING}

None.

\section{DATA AVAILABILITY}

All datasets generated or analyzed during this study are included in the manuscript and/or the Supplementary Files.

\section{ETHICS STATEMENT}

Not applicable.

\section{REFERENCES}

1. Ahmed FHE, Badri AA, Ibrahim MM, EL shahed AS, EL khalafawy HM. Comparative studies of antifungal potentialities for some natural plant oil against different fungi isolated from poultry Grasasy aceites. 1994;45:260-264.

2. Al-Anzi MA. Study of damage between garlic extract and medicinal plant extracts against some human pathogenic fungi, Master Thesis, College of Science, University of Mosul. 2001.

3. Al-Noman A. The molecular effect of some plant extracts on the growth and metabolism of a number of positive and gram-negative bacteria, PhD thesis, Faculty of Science, University of Mosul. 1998.

4. Arak EH. "Result of essential oil analysis of pineapple food and wild chamomile by gas chromatography method". In: Abstract Book of II congress of Estonian Pharmacists. Tallinn. 1981:79-80.

5. Benke ES, Rogers AL. Medical Mycology Manual $4^{\text {th }}$ Ed. 1980.

6. Burgess Publishing Co.: Minnesota, U.S.A. Int. Congr Medicinal plants. Hungary, Abstr. Sec. B. 1979:273.

7. Bodey GP. Fungal infections in cancer patients Annals, Academy of Sciences, New York. 1988;544:431-442.

8. Bruneton J. Pharmacognosy Phytochemistry Medicinal Palnts. Technique and Documentation Edition medicales internationales, France. $2^{\text {nd }}$ edition. 1999:335 and 545-547.

9. Chakravarty HL. Plant wealth of Iraq. SreeSaraswaty Press Ltd. Clacutta, India. 1976;1:184-185.

10. Collee JG, Fraser AG, Marmoin BP, Simmons A. Practical Medical Microbiology, $4^{\text {th }}$ ed., Churchill Livingstone, U.K. 1996;695-717.

11. Edmonds P. Microbilogy, an environmentl perspective Macmillan publishing CO.Inc. 1978.

12. Eilabib MS, Khalifa ZM. Dermatophytes and other fungi associated with skin mycoses in tripoli, Libya. Ann. Saudi Med. 2001;21:193-195. doi: 10.5144/02564947.2001.193

13. Emmons CW, Binford CH. Utz JP. Medical Mycology. Second ed., Lea and Febiyer Philadelphia, U.S.A. 1970.

14. Evans WC. Trease and Evans pharmacognosy. fourteenth Ed., Sanders Co., London, UK. 1997.

15. Forbes BA, Sahm DF, Weissfeld AS.Diagnosis Microbiology.11th ed., Mosby Inc. New York, U.S.A. 2002:1069.

16. Franz C. Int. Congr Medicinal plants. Hungary. 1979:273.

17. Georgorapadakou NH. Biological and biochemical science: Antibiotic. McGraw-Hill, USA. 2000.

18. Gradiner P.Chamomile(Matricriaveculita, Anthemisnobilis). Longwood Herbal Task Force. 2000;40:21-27.

19. Harborne JB. Phytochemical methods a guide to modern techniques of plants analysis. Chapman and Hall Ltd. London. 1973:159-165.

20. Hunter JAA, Savin JA, Dahl MV. Clinical Dermaatology. 
3nd ed., Blakwell Science. 2002:214-221.

21. Jawetz E, Melnick JL, Adelberg EA. Review of Medical Microbiology, $17^{\text {th }}$ ed. Prentice. Hall International U.S.A. 1987;595.

22. Koneman EW, Roberts GD, Wright SE. Practical Laboratory Mycology 2nd ed.The Williams and Wilkins, Bultimore, U.S.A. 1979;153.

23. Lai F, Loy G, Manconi M, Manca ML, Fadda A .Artemisia arborescensz essential oil loaded beads preparation and characterization. AAPS Pharm. Sci. Tech. 2007;8;E126-E132. doi: 10.1208/pt0803067

24. Liang YC, Huang YT, Tsai SH, Lin-Shiau SY, Chen CF, Lin JK. Suppression of inducible cyclooxygenase and inducible nitric oxide synthase by apigenin and related flavornoids in mouse macrophages: Carcinogenesis. 1999;20:1945-1952. doi: 10.1093/carcin/20.10.1945

25. Majeed, Sami, Jamil. Iraqi plants and herbs between folk medicine and scientific research. First Edition, Revolution House Press, Baghdad, Iraq. 1988.

26. Mann C, Stab J. The chemistry pharmacology, and commercial formulations of chamomile, in herbs, species and medicinal plants:Recet Advances in Botanay, Horticulture, and pharmacology, Vol 1, L.E. Craker, J.E. simon eds.oryx press, phoenix, Arizona. 1986;233-280.USA.

27. Mansour AT. The complete guide to medicinal herbs and medicinal plants. Second edition, Al-Ahlia Publishing and Distribution, Amman, Jordan. 2005.

28. Matsamato T. Fugal diseases in dermatology. In: Principles and Practice of Clinical Mycolgy and Jousson by Kibbers CC, Mackenzie DWR and Odd FC, (eds), John wiley and sons, Ltd, New York, USA. 1996.
29. Mimica-Dukic N, Simin N, Cvejic J, Orcic D, Bozin B. Phenolic compounds in field horsetail (Equisetum avvense) as natural antioxidants. Molec. 2008;13:14551464. doi: 10.3390/molecules 13071455

30. Mustafa AT .Chamomile, its qualities, components and multiple regions, and the scientific symposium specialized in chamomile research, College of Pharmacy, University of Mosul. 2004.

31. Newall CA, Phillpson JD. "Herbal Medicines: A Guide for Health-Care Professionals". London: Pharmaceutical Press. IX. 1996:296.

32. Pitt JI, Hocking AP. Fungi and Food spoilage, $2^{\text {nd }}$, Academic Press, Sydney, Australia. 1997:593. doi: 10.1007/978-1-4615-6391-4

33. Qubaisi H. Dictionary of Herbs and Medicinal Plants, Dar Al-Kutub Al-Ilmiyya, Beirut, Lebanon. 1998.

34. Ramos MF, Santos EP, Bizarri CH, Mattos HA, Padilha MR, Duarte HM. Preliminary studies towards utilization of various plant extracts as antisolar agents. Int J Cosmet Sci. 1996; 18(3):87-101. doi: 10.1111/j.14672494.1996.tb00140.x

35. Revenchon E, Senatore F. Super critical carbon dioxid extraction of chamomile essential oil and its analysis by gas chromatography mass spectrometry. J Agric Food Chem. 1994;42:154-158. doi: 10.1021/jf00037a027

36. Rios JL, Recio MC, Villar A. Antimicrobial activity of selected plants employed in the Spanish Mediterranean area. J E Ethnopharmacol. 1987;21:139-152. doi: 10.1016/0378-8741(87)90124-3

37. Szepietawski JC, Sehwart RA. Tinea barbaeUmdnj-New Jersew Medical School USA. 2005.

38. Virella G. Microbiology and Infections Diseases Williams and Wilkins, London, U.K. 1997;343. 